\title{
SUID-AFRIKA EN DIE IMPERIALE GENERALE STAF-GEDAGTE
}

\section{INLEIDING}

Met betrekking tot militêre beplanning of, na aanleiding van die afwesigheid van 'n militêre organisasie wat met hierdie taak belas was, het die Britşe militêre owerhede tydens die Anglo-Boere-oorlog 'n gedugte les geleer.

Daar is terdeë besef dat die War Office in dié opsig hervorm moet word en dit was hierdie besef wat in 1903 tot die totstandkoming van die War Office (Reconstruction) Committee, onder voorsitterskap van lord Esher, gelei het.

Hierdie komitee, wat ookal as gevolg van sy verstrekkende aanbevelings, as die Esher-komitee bekendheid verwerf het, het o.m. 'n permanente adviserende organisasie bepleit met as vernaamste funksie die insameling en verwerking van informasie. Op grond hiervan sou dan 'n oorlogsbeleid beplan word met as vereiste die tydige tref van doeltreffende maatreëls in vredestyd.

Lord Esher het die funksie van die beoogde organisasie soos volg omskrywe:

The scientific study of Imperial resources, the co-ordination of the ever-varying facts upon which Imperial rule rests, the calculation of forces required, the broad plans necessary to sustain the burden of the Empire...'

Hierdie studie was aldus F. A. Johnson, geensins tot die Britse eilande beperk nie, maar het die hele Britse ryk - waarvan Brittanje die erkende leier was behels ${ }^{2}$.

Die opvatting en lord Esher se siening dat hierdie werksaamhede nie tot vredestydse administratiewe bedrywighede ten opsigte van die toenmalige Britse landen seestrydkragte beperk moet bly nie, maar dat daar ook nadruk op militêre beplanning en strategiese beplanning gelê moet word, plaas die toenmalige Britse ryk en sy verdedigingsvraagstukke in die middelpunt van belangstelling.

Johnson het hierdie probleemstelling soos volg geformuleer:

The British Empire is pre-eminently a great Naval, Indian and Colonial power. There are, nevertheless no means of co-ordinating defence problems, or for dealing with them as a whole, for defining the proper functions of the various elements, and for ensuring that, on the one hand, peace preparations are carried out upon a consistent plan, and, on the other hand, a definite war policy based upon solid data can be formulated ${ }^{3}$.

Hierdie funksie is aan die reeds bestaande Committee of Imperial Defence toevertrou wat, na aanleiding van die bevindings van die Esher-komitee, vanaf 1904 'n nuwe, nou deeglik geformuleerde en bygevolg doelbewuste koers, ingeslaan het en deur die Colonial Defence Committee bygestaan is om die nuwe oogmerke te probeer verwesenlik.

Weliswaar het die Britse dominiums, waaronder Suid-Afrika, saam met die toenmalige Britse kolonies oor magtige militêre hulpbronne beskik, maar tot die daarstelling van die Imperiale Generale Staf het 'n organisasie ontbreek om, in geval van oorlog, dié hulpbronne te benut. Laasgenoemde liggaam sou 'n belangrike leemte in die militêre organisasie van die Britse ryk vul'. 


\section{1 \\ DIE IMPERIALE KONFERENSIE VAN 1907}

a. Die behoefte aan 'n Imperiale Generale Staf besef

Tydens die Imperiale konferensie van 1907 is die behoefte aan 'n Imperiale Generale Staf, ,selected from the forces of the Empire as a whole," terdeë besef en is die funksie van so 'n organisasie in vredestyd soos volg omskrywe:

To study military science in all its branches: to collect and disseminate to various governments military information and intelligence; to undertake the preparation of schemes of defence on a common principle, and (without in the least interfering in questions connected with Command and administration) at the request of the respective governments, to advise as to the training, education, and war organisation of the military forces of the Crown in every part of the Empire.

Behalwe dat hierdie behoefte nou deeglik geformuleer en die funksies van die beoogde Imperiale Generale Staf noukeurig omskrywe is, is terselfdertyd besluit dat die hoof van die Britse Generale Staf voorstelle met betrekking tot die uitvoering van die besluit moet indien. $\mathrm{Na}$ aanleiding van hierdie besluit het genl. sir W. G. Nicholson sy memorandum The Imperial General Staff op 7 Desember 1908 gereed gehad.

\section{b. Genl. sir William Nicholson se memorandum}

Voordat gınl. Nicholson in sy memorandum tot die kern van die vraagstuk deurgedring het, is deur hom op die volgende feite gewys:

i. Die feit dat Brittanje aan die vooraand van die daarstelling van militêre magte in die dominiums staan.

ii. Die feit dat die Britse ryk 'n stadium bereik het waarin die dominiums voel dat hulle sterk genoeg is om meer verantwoordelikheid vir die verdediging van hul eie tuistes te aanvaar.

iii. Die dominiums beskou dit nie slegs as 'n plig nie, maar as 'n reg wat hulle toekom.

iv. Tans het die dominiale regerings met die vraagstuk te kampe op watter wyse hierdie gevoel in die regte kanale gelei moet word.

v. Om leiding in hierdie verband te kan verstrek, is die daarstelling van 'n Imperiale Generale Staf van wesentlike belang.

Op grond hiervan, aldus genl. sir William Nicholson, wil dit voorkom dat die onderwerp van bespreking soos volg ingedeel moet word:

i. Die algemene beginsels aangaande nasionale verdediging 5 .

ii. Die doeltreffendheid van 'n Imperiale Generale Staf.

iii. Die beginsels waarvolgens offisiere vir die toekomstige Imperiale Generale Staf uitgesoek en opgelei moet word.

Die generaal lê vervolgens nadruk op die feit dat daar in verskeie dominiums, sowel as in Engeland, maatreëls getref word om plaaslike militêre hulpbronne te ontwikkel, met dié bedoeling om die plaaslike verdediging op 'n stewiger en praktieser grondslag te organiseer. Met die toenmalige groeiproses van die Imperiale ideale het die versterkte gevoel gepaard gegaan dat dit wenslik is dat die militêre magte van die Britse ryk hegter saamgesnoer moet word. 
In dieselfde lig moet ook die begripsinhoud van die term nasionale verdediging gesien word. Genl. Nicholson het in dié verband verklaar dat hierdie term betrekking het op die plaaslike sowel as op die Imperiale verdediging en aangaande eersgenoemde aspek verklaar:

As regards local defence in each case the object to be kept in view, which should govern the standard to be striven for, is to provide, organize, and render efficient such means of defence as will form by their existence a serious deterrent to the most probable and feasible form of attack.

Die opsteller het hieraan toegevoeg:

.. . these means should be adequate to enable each particular division of the Empire to secure against reasonable initial contingencies; while, in the event of more serious hostile undertakings, the organization and means should be sufficient to enable the issue to be deferred until the naval and military resources of the Empire can be concentrated at a decisive point or points.

Ten opsigte van die Imperiale verdediging geld die volg’nde stelling: Geen verdedigingsorganisasie kan as toereikend of volledig beskou word nie wanneer dit geen offensiewe optrede in aanmerking neem nie. Want, so voeg genl. Nicholson aan hierdie uitspraak toe: Slegs selde is daar, as grvolg van passiewe verdediging, beslissende resultate behaal.

Uitgaande van die besluit van die Imperiale konferensie van 1907 aangaande die noodsaaklikheid van konsentrasie van die Imperiale magte ten opsigte van die verdediging van die Britse ryk, lê die generaal die stelling neer dat die omvang van dergelike troepekonsentrasies van die betrokke Imperiale belange afhang en bestaan die moontlikheid dat hierdie magte hulp sal moet verleen aan dié magte wat vir plaaslike verdedigingsdoeleindes in 'n bepaalde deel van die Britse ryk op die been gehou word.

Om in so 'n geval die beste resultate te kan behaal, bepleit genl. Nicholson die noodsaaklikheid van eenvormigheid van organisasie om militêre optrede in noue samewerking moontlik te maak.

Om hierdie stelling die nodige trefkrag te gee, verwys hy na 'n memorandum wat in 1907 aan die Imperiale konferensie voorgelê is, om daarna te verklaar:

Combination of effort is a fundamental principle of war, and the existence of different schools of thought in an army is fatal to such combination.

The ideal to be arrived at is that all divisions of a military force should be capable of acting in war as parts of a whole. This ideal can only be fully realized when all the parts are organized and trained by one brain, and in the modern army that is the General Staff.

The General Staff must therefore be an entity throughout the Empire, and to make it so, all its members ought to be uniformly trained in principles and practice in one school under one head.

Met betrekking tot die noodsaaklikheid om oor 'n sentrale, leidinggewende militêre organisasie vir die beplanning van die verdediging van die Britse ryk, vir die bestudering van beginsels en die insamel en verspreiding van informasie te beskik, het genl. Nicholson ook die noodsaaklikheid van plaaslike takke bepleit. Hierdie takke kan dan plaaslike behoeftes en moontlikhede bestudeer en toesig oor die 
aanwending van die algemene beginsels onder plaaslike omstandighede hou. Tewens moet onthou word dat bogenoemde takke ondergeskik aan die toekomstige Imperiale Generale Staf moet wees.

Dieselfde gedagte, nou met betrekking tot een sentrale, alomvattende organisasie, beklemtoon die generaal weer, wanneer hy skrywe:

Thus, both in peace and war, the General Staff must be regarded as a large organization, consisting of a central body, with branches stretching out to all the various units of the army.

Ten opsigte van die sentrale organisasie, die beoogde Imperiale Generale Staf, verklaar hy dan met betrekking tot die vereistes van die lede en die taak:

If it is to carry out the duties allotted to it efficiently and to act as the guiding and directing spirit - the "brain" - of the whole army, it is evident not only that all its members must be highly educated and trained, but that its work must be carried out on common principles in all parts of the Empire. It is, therefore, a necessity that the Imperial General Staff should have one recognised head to ensure uniformity of method and purpose.

Hierdie hoof kan, volgens die generaal, alleen die Hoof van die Generale Staf in Londen wees. Hy moet, indien daar 'n doeltreffende organisasie begeer word, hoof van die Imperiale Generale Staf word.

Daarna moet, onder sy toesig, die Generale Staforganisasie van die Britse ryk ooreenkomstig die volgende beginsels opgebou word:

i. Allereers moet 'n sentrale organisasie, met Londen as Hoofkwartier, daargestel word, wat regstreeks onder die Hoof van die Imperiale Generale Staf ressorteer.

ii. Plaaslike takke moet in die Verenigde Koninkryk, in elkeen van die buitelandse Britse garnisoenstede, in die selfregerende dominiums en Indië in die lewe geroep word; met dien verstande dat die plaaslike afdelings of takke, met uitsondering van die kleiner buitelandse garnisoene, in dié plaaslike hoofkwartier en die staf by die plaaslike troepemagte onderverdeel word. Elkeen van dié afdelings behoort 'n hoof in bevel te hê en moet vraagstukke met betrekking tot plaaslike verdediging en die opleiding van troepe ooreenkomstig die opleidingsmetodes wat tans in die Verenigde Koninkryk in gebruik is, hanteer.

Met betrekking tot die samewerking tussen die Hoof van die Imperiale Generale Staf en die hoofde van plaaslike Generale Stawe in die dominiums verklaar genl. Nicholson:

In this organization, as applied to the self-governing Dominions, each Chief of a local section of the General Staff, would be the adviser of his own Government as well as the head of all General Staff Officers in his section whether at his headquarters or with the troops.

Die vraag hoe die verhouding tussen die Hoof van die Imperiale Generale Staf en die hoofde van plaaslike afdelings van die Generale Staf in elkeen van die verskillende dominiums moet wees, beantwoord genl. Nicholsol soos volg: Die Hoof van die Imperiale Generale Staf moet, met betrekking tot alle suiwer militêre aangeleenthede, leiding gee.

Andersyds het die generaal terdeë besef dat so 'n beleid onverenigbaar sal wees met die beginsel van volledige beheer wat 'n dominiale regering oor die hoof van sy eie Generale Staf uitoefen. 
Om moontlike wrywings of botsings in dié verband uit te skakel, het hy dan ook met die volgende voorstel gekom:

... that, while the Chiefs of the local sections of the General Staff keep in close communication with the Chief of the Imperial General Staff, they cannot receive orders from him.

Die posisie van die Hoof van die Imperiale Staf is soos volg deur genl. sir William Nicholson omskrywe:

He will keep them informed as to what are considered the correct principles, and they will advise their governments as to the best method of applying these principles to local conditions, and as to the risk of departing from them. When their advice is not accepted, it will be their duty to carry out whatever their respective governments may order.

Ook al op grond van hierdie konstitusionele haakplek wat die doeltreffendheid van die beoogde organisasie dalk kon benadeel, het genl. Nicholson die mening uitgespreek dat die beste metode om eenvormigheid te verkry daarin geleë is dat toekomstige offisiere vir die Imperiale Generale Staf uitgesoek, gelyklik onderrig en opgelei word, dat tot 'n stelsel van periodieke uitwisseling van opgeleide offisiere in die ryk oorgegaan word en van tyd tot tyd konferensies gehou word om gedagtes te wissel. Tewens beveel hy aan dat lede van die Imperiale Generale Staf na een van die plaaslike afdelings uitgestuur word om dan tot die gevolgtrekking te kom dat 'n kombinasie van die twee metodes die beste sal wees.

Met verwysing na die oorlogstydse organisasie van die Imperiale Generale Staf lui sy oordeel soos volg:

In a great war the General Staff officers with the troops would be furnished chiefly from those serving in the local sections from which the troops were drawn, while those attached to the supreme commander in the field would be mainly drawn from officers who had proved their efficiency on the central body of the Imperial Staff.

Genl. Nicholson se opmerking dat offisiere wat - sowel in vredes- as in oorlogstyd - as lede van die Imperiale Generale Staf benoem word, nie alleen die vertroue van militêre kant nie, maar ook van die Imperiale en dominiale regerings van die Britse ryk moet besit. Dit kan slegs verkry word deur offisiere in die Imperiale Generale Staf op te neem, wat oor gespesialiseerde, persoonlike en praktiese kennis van sowel militêre as politieke plaaslike omstandighede in alle dele van die Britse ryk beskik.

Met betrekking tot die uitsoek en opleiding van toekomstige offisiere in die Imperiale Generale Staf stel genl. Nicholson as eerste voorwaarde, dat hierdie offisiere eers oor 'n sekere gemeenskaplike peil van militêre kennis moet beskik en met die vereiste eenvormigheid van denke en die praktiese toepassing hiervan vertroud moet wees, voordat hulle tot die Imperiale Generale Staf kan toetree. Hierdie ideaal kan deur 'n stafkollege-opleiding verwesenlik word en in dié verband beveel die generaal aan dat die bestaande stafkollege op Camberley, wat onder regstreekse toesig van die Hoof van die Imperiale Generale Staf staan, binne die eersvolgende paar jaar as dié sentrale opleidingsinrigting vir hoër militêre opleiding vir die hele Britse ryk erken word. Hiermee het genl. Nicholson egter nie bedoel dat die bestaande stafkollege in alle Imperiale opleidingsbehoeftes sou voorsien nie, omrede hy 'n toekomstige uitbreiding van militêre opleidingsinrigtings dwarsdeur die Britse ryk in gedagte gehad het. 
In so 'n geval sal Camberley nie in staat wees om in meer as die behoeftes vir die Britse ryk se garnisoenstede, met inbegrip van Indië, te kan voorsien nie. Tewens het hy die waarde van persoonlike aandag en indiwiduele onderrig besef en op grond hiervan tot die gevolgtrekking gekom dat te veel offisiere in een sentrum opgelei sou word en dat in so 'n geval die indiwiduele opleiding beslis daaronder sou ly. Om aan dié gevaar te ontkom, het hy desentralisasie aanbeveel en verklaar:

... if the self-governing dominions beyond the seas are ever to become self-contained in their military institutions, they themselves will, sooner or later, recognize the necessity. Such decentralization should take the form of an educational establishment on similar lines to, and worked in close connection with, the Staff College at Camberley, for each great division of the Empire.

Tot tyd en wyl hierdie behoeftes sou ontstaan, moes offisiere aangemoedig word om die doeltreffendste gebruik van bestaande opleidingsinrigtings, soos die Stafkollege op Camberley en die Indiese Stafkollege op Quetta, gebruik te maak.

Nadat genl. Nicholson nadruk op eenvormige toelatingsvereistes en leergange gelê het, het hy ten slotte tot die volgende, besonder belangrike gevolgtrekking gekom: Officers composing the central body of the Imperial General Staff must be the pick of the officers of the whole Empire who are qualified for General Staff work. They should be retained in that employment only as long as they prove themselves fitted for it.

They should, as far as possible, before appointment to the central body, have served on the local staffs both at home and abroad. They should be nominated on the advice of the Chiefs of the local General Staffs or as in regards officers serving in India by the Commanderin-Chief in India, subject to the concurrence of the Chief of the Imperial General Staff.

Die groot ideale wat genl. Nicholson voor oë gestaan het, was dat die dominuums en Indië uiteindelik en, met betrekking tot die voorsiening van behoorlik gekwalifiseerde offisiere vir hul onderskeie afdelings, ten opsigte van hulle generale stawe self onderhoudend moet wees. Terselfdertyd moet 'n aantal van hierdie offisiere in die toekoms lede van die sentrale liggaam van die Imperiale Generale Staf word. Hierdie offisiere kan dan, na voltooiing van hul dienstydperk, as lede van die sentrale organisasie of van die plaaslike afdeling na die troepe teruggaan tot tyd en wyl hulle weer stafaanstellings ontvang.

Op die vraag watter personeel tans (in 1908) beskikbaar is en watter opleidingsmoontlikhede daar reeds vir toekomstige offisiere vir die Generale Staf bestaan, antwoord genl. Nicholson dat die Britse ryk, met betrekking tot sy militêre magte, soos volg ingedeel kan word:

i. Die Verenigde Koninkryk en dié Britse besittings waarvan die verdediging en die militêre organisasie regstreeks onder die gesag van die moederland val.

ii. Indië, waar sowel Britse en Indiëse garnisoene is en waaroor die beheer hoofsaaklik by die Indiëse Regering berus, ofskoon die War Office sekere magte met betrekking tot die Britse troepe in Indië uitoefen.

iii. Die dominiums waarin die militêre diens en organisasie deur plaaslike regerings gereël word en wat in die dominiums Kanada, Australië, Nieu-Seeland en Suid-Afrika onderverdeel word. 
In eersgenoemde geval bestaan die Stafkollege op Camberley, 'n georganiseerde Generale Staf wat oor jarelange ervaring beskik en 'n paar duisend offisiere wat tot op 'n sekere peil opgelei is. Tewens is daar 'n georganiseerde en beproefde masjinerie om die bestes van hierdie offisiere vir gevorderde onderrig en opleiding uit te soek, terwyl daar ook oor die vereiste geriewe beskik word om hulle op die beste wyse te onderrig en op te lei.

In Indië is die omstandighede grotendeels dieselfde. 'n Plaaslike stafkollege is in 1905 ge-open, die leerplan is ongeveer soos Camberley s'n en aangesien die kommandant en een-derde van die doserende personeel op Camberley opgelei is, kan 'n eenvormige opleiding verseker word.

In die dominiums is die omstandighede uiteenlopend. Op die oomblik (1908) beskik slegs Kanada oor 'n nasionale militêre opleidingsinrigting wat met dié van Woolwich en Sandhurst vergelyk kan word.

Nieteenstaande hierdie uiteenlopende omstandighede bepleit genl. Nicholson die noodsaaklikheid van die onverwylde daarstelling van 'n Imperiale Generale Staf omrede, in gevalle waar die dominiums aanmerklike uitbreiding van hul militêre magte ooreenkomstig die nuwe beginsels oorweeg, die daarstelling van doeltreffende afdelings van die Imperiale Generale Staf vir organisatoriese- en opleidingsdoeleindes uiters noodsaaklik is om 'n eenvormige beleid te kan deurvoer.

Op grond van alles wat deur hom genoem en beklemtoon is, vereis die volgende aanbevelings dan onmiddellik aandag om die grondslae vir 'n Imperiale Generale Staf te lê:

i. Al die gewapende magte van die Britse ryk moet, in die besonder waar dit bevelvoering en stafpligte betref, vir oorlogsdoeleindes ooreenkomstig dieselfde beginsels georganiseer word. Op grond hiervan moet daar met die stigting van die Imperiale Generale Staf voortgegaan word.

ii. Eenvormigheid moet, met betrekking tot die opleiding van offisiere vir die Generale Staf verseker word, deur reëlings te tref aangaande die eenvormige opleiding van regimentsoffisiere wat as toekomstige studente vir die stafkolleges bedoel is, deur 'n eenvormige keuringsprosedure van genoemde offisiere vir stafkollege kursusse deur eenvormige toelatingseksamens, leerplanne en onderrig aan die verskillende stafkolleges, deur eenvormigheid ten opsigte van die uitvoering van stafpligte en deur graduandi van die stafkolleges aan te moedig om verdere opleidingskursusse in Engeland of Indië te volg. Nog 'n belangrike aspek wat in dieselfde verband genoem is, is dat reëlings vir 'n stelselmagtige uitruiling van offisiere van die Imperiale Staf oor die lengte en breedte van die Britse ryk getref moet word.

\section{c. Die Britse Leërraad lig die Britse Departement van Kolonies in}

Op 15 Desember 1908 het die Britse Leërraad 'n skrywe aan die Departement van Kolonies gerig waarin, met verwysing na voorafgaande korrespondensie en die besluite wat tydens die Imperiale konferensie van 1907 geneem is, verklaar is dat die Raad van oordeel is dat:

i. Die Britse opperheerskappy op see noodsaaklikerwyse gehandhaaf moet word omdat slegs op dié wyse militêre samewerking verseker kan word.

ii. Dit wenslik is om 'n militêre organisasie in die Britse ryk op 'n breë grondslag daar te stel, maar dat daar, binne die raamwerk van hierdie plan, plek vir plaaslike omstandighede ingeruim moet word. 
iii. Die gewapende magte van die Britse ryk in twee onderdele georganiseer moet word, t.w. 'n onderdeel wat die plaaslike verdediging behartig, en 'n ander onderdeel wat vir diens oor die lengte en breedte van die Britse ryk aangewys is.

Behalwe dat daar onder para. ii na die toekomstige Imperiale Generale Staf verwys is, is die volgende uiteensetting met betrekking tot die dominiums toegevoeg:

The Army Council are well aware that the self-governing Dominions can give no guarantee that contingents of any strength or composition will be forthcoming for service in any part of the Empire in the event of a great war.

At the same time, they fully realise that the feelings of loyalty and affection towards the Mother Country entertained by the Overseas Dominions will operate as powerfully in the hour of trial, as they did during the recent war in South Africa.

Vervolgens is, met die oog op die toekomstige organisasie van die ryksverdediging en met verwysing na die verlede verklaar:

But the lack of definite provision for an emergency deprives military forces of much of their potential value, while adequate preparation has been proved in all recent campaigns to be a paramount factor in seeming a rapid and successful decision.

For these reasons, although the Overseas Dominions may be unable to undertake definite responsibility for anything beyond local defence, to consider the necessities incidental to a situation in which the Dominions beyond the seas desired to provide effective military service in association with the troops of the Mother Country.

In dieselfde skrywe is dit, nadat na die belangrikheid verwys is om die algemene beginsels "of the higher organisation of units" - soos daaromtrent deur die Imperiale Konferensie van 1907 besluit is - vir die praktyk deur te voer, aan die Minister van Kolonies oorgelaat om die inhoud van die skrywe aan die dominiale regerings kenbaar te maak.

Laasgenoemde Minister het op 8 Januarie 1909 die memorandum van genl. sir William Nicholson en die verklaring van die Leërraad aan die adjunk-Goewerneur van Transvaal, genl. lord Methuen, gestuur wat alles - op sy beurt op 28 Januarie 1908 aan die Eerste Minister van Transvaal, genl. Louis Botha, deurgestuur het.

\section{d. Genl. Botha lê die vraagstuk aan kol. Beves voor}

Genl. lord Methuen het, in sy begeleidende skrywe aan die Transvaalse Eerste Minister, verklaar dat die Britse Minister van Kolonies graag telegrafies sal verneem of die Transvaalse premier en sy kabinet die beginsels, soos neergelê in die Nicholson-memorandum met betrekking tot die daarstelling van 'n Imperiale Generale Staf, sal aanvaar.

Nadat genl. Botha op 13 Februarie 1909 deur goewerneur lord Selbourne aan hierdie versoek herinner is, het kol. P. S. Beves, inspekteur van die „Transvaal Volunteers" op 23 Februarie 1909 met sy verslag "On the suggestion to form an Imperial General Staff' gereedgekom.

\section{e. Kol. Beves se bevindings}

Met verwysing na genl. Nicholson se memorandum het kol. Beves onder meer verklaar dat hy die planne, soos deur die Hoof van die Britse Generale Staf voorgestel, in beginsel soos volg sien: 
A most important move in connection with reciprocity as far as the various forces of the Imperial Army and the colonies are concerned ..

Die kolonel het verder onder meer die waarde van die Camberleystafkollege sterk beklemtoon en aan die slot van sy bevindings verklaar dat die gedagtes aangaande die daarstelling van 'n Imperiale Generale Staf kerngesond is en dat daar, syns insiens, onverwyld met die uitvoering begin moet word.

\section{f. Genl. Botha vra uitstel}

Genl. Louis Botha het op 7 Maart 1909 aan die goewerneur van Transvaal meegedeel dat die Transvaalse regering ten gunste van die daarstelling van 'n Imperiale Generale Staf is. Tewens het hy die aandag gevestig op die feit dat die „Transvaal Volunteers" die beginsels van die Britse leërorganisasie soveel as moontlik in sy eie organisasie toepas.

Aan die slot van sy skrywe het die Eerste Minister ewenwel verklaar:

Ministers desire however to point out that matters in South Africa are at present in a state of transition and under the circumstances they would prefer not to make any declaration which might have the effect of not leaving to the future Government of Unified South Africa a free hand to deal with this important matter.

\section{g. Die sienswyse van Kanada en Australie}

Waar genl. Botha, in Maart 1909, enersyds te kenne gegee het dat hy in beginsel ten gunste van die daarstelling van 'n Imperiale Generale Staf is, maar andersyds die beslissing aan die toekomstige Unieregering wou oorlaat, het die Kanadese regering reeds op 9 Februarie 1909 aan die Britse War Office meegedeel dat:

i. Die daarstelling van die Imperiale Generale Staf in beginsel goedgekeur word.

ii. Die beginsel van volledige plaaslike beheer, m.a.w. van koloniale of dominiale selfbestuur, in die gedrang kom.

In dieselfde memorandum het die Kanadese Minister van Milisie en Verdediging, sir F. W. Borden, K.C.M.G., dan ook nadruk gelê op die feit dat die Hoof van die plaaslike Generale Staf, in hierdie geval dus van die Kanadese Generale Staf, ten volle deur sy regering beheer moet word.

Op grond van hierdie beginsel het hy dan ook voorgestel dat:

all communications passing between the Chief of the Canadian Section and the Chief of the Imperial General Staff, other than those on purely routine or ephemeral questions, must be submitted to the Minister of Militaria for his concurrence before being dispatched.

Op hierdie wyse sou, aldus die minister, die selfstandigheid van sy dominium onaangetas bly. Hierdie sienswyse is sowel deur die Kanadese Komitee van die Geheime Raad as deur die Goewerneur-generaal van Kanada beaam. Deur Australië is 'n soortgelyke houding ingeneem.

Bogenoemde beleidsverklarings het die daarstelling van onbeperkte alomvattende militêre beheer deur die toekomstige Imperiale Generale Staf oor die gesamentlike strydmagte van die dominiums op dié stadium reeds uitgeskakel en onder meer bewys gelewer van die bestaan van desentraliserende kragte in die Britse ryk wat, na verloop van tyd, al hoe sterker sou word.

Suid-Afrika kon, as gevolg van die staatkundige oorgangstoestand, op dié tydstip geen duidelike koers aandui nie. 


\section{2}

\section{BESPREKINGS TYDENS DIE IMPERIALE KONFERENSIE VAN 1909}

\section{a. Uitnodiging uitgestuur. Genl. Botha se houding}

Op 30 April 1909 is, namens die Eerste Minister van die Verenigde Koninkryk, o.m. uitnodigings aan die premiers van Australië, Nieu-Seeland, die Kaapkolonie en Newfoundland gestuur om die aanstaande Imperiale konferensie aangaande ryksverdediging in Londen by te woon.

Aan die Eerste Minister van die Kaapkolonie is onder meer geskrywe dat besef word dat die regering van hierdie kolonie net soos die ander regerings van SuidAfrika, die moontlikheid van die daarstelling van 'n unie oorweeg. As gevolg hiervan sal hulle dalk nie in staat wees om 'n werksame aandeel aan die konferensie te neem nie. Andersyds word besef dat die afwesigheid van Suid-Afrikaanse verteenwoordigers hinderlik sal wees?

Die uitnodiging wat aan Eerste Minister John X. Merriman gerig is, is ook aan die premiers van die ander Britse kolonies in Suid-Afrika versend en op 10 Mei 1909 het die goewerneur van Transvaal geantwoord dat genl. Botha besonder begerig is om die uitnodiging namens sy regering te aanvaar. Met die oog op die aanstaande konstitusionele veranderings sal dit ewenwel onmoontlik wees om 'n besonder werksame aandeel in die besprekings te hê of om enige beleid te aanvaar wat die toekomstige Unieregering sal bind.

Genl. Botha en sy kollegas was, aldus dieselfde mededeling, op dié tydstip ewenwel van mening dat die aanwesigheid van Suid-Afrikaanse afgevaardiges die toekomstige Unieregering dalk sou help om 'n Suid-Afrikaanse verdedigingstelsel te formuleer wat, sover moontlik, in ooreenstemming met dié in ander dele van die Britse ryk sou wees.

Die Transvaalse Eerste Minister stel dan ook voor dat dié Suid-Afrikaanse afgevaardigdes, wat in verband met die Suid-Afrikawetsontwerp na Londen gaan, Transvaal op die Imperiale konferensie verteenwoordig8.

Soortgelyke antwoorde is van die goewerneurs van die Kaapkolonie, die Oranjenivierkolonie en Natal ontvang?.

Op 28 Julie 1909, die dag waarop die eerste byeenkoms van die Imperiale konferensie in Londen gehou is, was die Suid-Afrikaanse kolonies soos volg verteenwoordig: Die Kaapkolonie - Eerste Minister J. X. Merriman; Natal - Kol. E. M. Greene, K.C., Minister van Spoorweë en Hawens; Transvaal - Genl. J. C. Smuts, Koloniale Sekretaris; Die Oranjerivierkolonie - Eerste Minister A. Fischer, genl. J. B. M. Hertzog, prokureur-generaal ${ }^{10}$.

Sekere militêre vergaderings is deur brigadier-generaal G. G. Aston, C.B., en kol P. S. Beves bygewoon".

\section{b. Die Imperiale Generale Staf-gedagte}

Met betrekking tot die voorgenome ontwikkeling van die Imperiale Generale Staf is, nadat meegedeel is dat die dominiums die daarstelling van so ' $n$ organisasie in beginsel aanvaar het, tot die bespreking van voorstelle aangaande die verwesenliking van dié gedagte oorgegaan. 
Kanada en Australië het o.m. voorstelle ingedien waarin veral die noodsaaklikheid van 'n sentrale en plaaslike stafkolleges beklemtoon is. In dieselfde verband het die uitleen van bevoegde offisiere deur die Verenigde Koninkryk aan militêre opvoedkundige inrigtings in die dominiums en die tydelike uitruil van offisiere vir stafwerk in verskillende dele van dil Britse ryk ter sprake gekom. Tewens is beșluit om meer vrae in dié verband aan die dominiale regerings te stel ${ }^{12}$.

Terwyl die afgevaardigdes van die Verenigde Koninkryk, Kanada en Australië rigtinggewende werksaamhede verrig het, het Nieu-Stzeland geen voorstelle ingedien nie, terwyl aangaande Suid-Afrika soos volg gerapporteer is:

Has not yet accepted principles enunciated in Imperial Staff paper, owing to Transvaal, Cape Colony, Natal and Orange River Colony all being in agreement that, owing to the possible unification of South Africa, the present would be an inopportune time for the several Colonies to commit themselves to any engagement ${ }^{13}$.

\section{c. Ondersekretaris Bourne se oordeel}

Vermoedelik na aanleiding van 'n memorandum van die Hoof van die Imperiale Generale Staf in verband met die uitruil an toevoeg van offisiere van die Verenigde Koninkryk ten opsigte van die dominiums en die weiering om kapt. J. J. Collyer tot die Camberleystafkollege toe te laat, het Ondersekretaris H. R. M. Bourne op 17 Oktober 1910 'n stel aantekeninge oor die Imperiale Generale Staf opgestel.

Bourne was allereers van mening dat dié gedagte aan Duitsland ontleen was, waar so 'n organisasie as noodsaaklik beskou is om nie alleen eenvormigheid van organisasie en opleiding in die gewapende landstrydkragte van die onderskeie Duitse state te verkry nie, maar tewens om daadwerklike sentrale militêre beheer in oorlogstyd te verkry.

Hy was ook die volgende mening toegedaan:

War organization in the German Empire is now an undivided whole and it is not only removed from the control of the Government of the component states but for all practical purposes from the control of the Central Government or Reichstag.

Nadat Bourne tot die gevolgtrekking gekom het dat die Britse ryk sy verdedigingsmag nooit so streng eenvormig as die Duitse ryk kan organiseer nie, verklaar hy met betrekking tot die funksies van die twee stawe dat daar, sowel konstitusioneel as geografies gesien, byna geen ooreenstemming tussen die twee organisasies bestaan nie.

Bourne maak dan, met betrekking tot die funksies van die Britse Imperiale Generale Staf, die opmerking dat so 'n organisasie nie slegs 'n adviserende liggaam is nie, maar dat die verantwoordelikheid om krygsoperasies in oorlogstyd uit te voer, op die skouers van so 'n organisasie rus. Volgens hom dui die memorandum oor die daarstelling van 'n Britse Imperiale Generale Staf nie op die skepping van 'n ware Imperiale Generale Staf ooreenkomstig sy begripsinhoud nie.

Sou daar, so gaan hy verder, so 'n Imperiale Generale Staf in die lewe geroep word, dan sou dit inbreuk op die outonomie van die dominiums maak.

Op grond van laasgenoemde bevindings kom die Ondersekretaris vervolgens tot die hieronder aangehaalde gevolgtrekking:

None of the objects stated in that resolution and those papers, would while preserving colonial autonomy be less efficiently attained by discarding the misleading title and German analogy and by each 
So 'n Generale Staf, wat in elkeen van die dominiums sou bestaan, sou - aldus Bourne, - nog dieselfde funksies as die Imperiale Generale Staf uitoefen, naamlik om die militêre wetenskap te bestudeer, om militêre informasie in te samel en te versprei, om verdedigingskemas ooreenkomstig gemeenskaplike beginsels op te stel en om raad te gee met betrekking tot militêre opleiding en onderrig en oorlogsorganisasie.

Ten opsigte van bostaande het Bourne in gedagte gehad om, van die kant van die dominiums, die volgende verbintenisse by te voeg:

i. Om die Britse Leër van tyd tot tyd te versoek om offisiere vir diens op so 'n staf te sekondeer en om Britse stafoffisiere aan die Generale Stawe in die Verenigde Koninkryk of in Indië te verbind.

ii. Om Britse stafoffisiere aan die stawe van die dominiums en omgekeerd te verbind.

iii. Om deur middel van die briefwisseling die Generale Staf van 'n bepaalde dominium voortdurend met die ander Generale Stawe van die Britse ryk - en in die besonder met dié van die Verenigde Koninkryk, in verbinding te laat bly.

Weliswaar sou so 'n versameling van Generale Stawe as die Imperiale Generale Staf kan bekendstaan, maar dit sou, in Bourne se eie woorde:

tend to obscure still further a dividing line (which a process of cordial goodwill and co-operation in defence matters between the self-governing Dominions and the present country might easily tender somewhat faint) between the two conceptions of an Imperial General Staff'.

Binne die raamwerk van hierdie ondersoek is dit onmoontlik om vas te stel of bostaande uiteensetting, kritiek en aanbevelings tot sekere resultate gelei het of nie. Uit Ondersekretaris Bourne se gedagtegang kan in elk geval afgelei word dat hy bewus was van die bestaan en die uitwerking van teenoorgesteld gerigte kragte wat, in teenstelling met die sentraliserende gedagtes wat die grondslae van die Duitse Imperiale Generale Staf gekenmerk het, binne die raamwerk van die Britse Imperiale Generale Staf-organisasie werksaam was.

Op die eersvolgende Imperiale konferensie het verskillende swakhede van die ontplooiende Britse Imperiale Generale Staf-organisasie aan die lig gekom. Andersyds kon daar vordering gerapporteer word.

\section{DIE IMPERIALE KONFERENSIE VAN 1911 EN DIE IMPERIALE STAF}

\section{a. Doel van die konferensie}

Op 23 Mei 1911 het die afgevaardigdes van die Britse ryk onder voorsitterskap van Eerste Minister Asquith in Londen bymekaar gekom om 'n groot verskeiden- 
Behalwe die verteenwoordigers van die Verenigde Koninkryk het afgevaardigdes van Kanada, Australie,, Nieu-Seeland, Newfoundland en die Unie van Suid-Afrika aan die konferensie deelgeneem.

Die Unie is deur die Eerste Minister, genl. Louis Botha; die Minister van Openbare Werke, Pos- en Telegraafwese, sir David de Villiers Graaff; en die Minister van Onderwys, F. S. Malan, verteenwoordig. Die Sekretaris van Finansies, mnr. J. Leisk, het onder meer as privaat-sekretaris van die Unie se afvaardiging opgetree ${ }^{15}$.

Tydens die openingstoespraak het die Britse premier die doel van die konferensie soos volg geskets:

. . . to make the Empire, in all its activities, and throughout all its parts, a more complete and effective instrument for the furtherance of our corporate unity and strength along the old, welltrodden, but ever lengthening and widening road, of British liberty ${ }^{16}$.

\section{b. Verdedigingsaangeleenthede. Die dominiums. Suid-Afrika}

In die loop van dieselfde toespraak is, ooreenkomstig die gebruik van 1909, voorgestel dat verdedigingsaangeleenthede vertroulik, en in aanwesigheid van verteenwoordigers van die dominiums, bespreek word ${ }^{17}$.

Aan die konferensie is, aangaande verdedigingsaangeleenthede, 'n aantal dokumente voorgelê waaronđer dié waarin die gemaakte vordering met betrekking tot die Imperiale Generale Staf gerapporteer is ${ }^{18}$.

Hierdie dokumente wat in die vorm van 'n blouboek, Imperial Conference, 1911. Dominions No. 9. Papers laid before the Imperial Conference: Naval and Military Defence, aan die konferensie voorgelê is, bevat 'n aantal besonderhede aangaande die vordering wat sedert die begin van 1909 ten opsigte van die Imperiale Generale Staf gemaak is ${ }^{19}$.

In Kanada is met die daarstelling van 'n plaaslike afdeling van die Imperiale Generale Staf begin, terwyl die Australiese afdeling in Augustus 1909 tot stand gekom het. In Nieu-Seeland is 'n soortgelyke organisasie in Desember 1910 gestig $^{20}$.

Die goewerneur-generaal van die Unie van Suid-Afrika het 'n amptelike skrywe van die Unieregering deurgestuur waarin die ontvangs van 'n memorandum oor die uitleen, sekondering en uitruil van stafoffisiere erken en waarin tewens verklaar is dat die regering nog nie in staat is om die werklike benodighede van die toekomstige Unieverdedigingsmag te bepaal nie. Ofskoon Suid-Afrika, as gevolg van die feit dat die toekomstige Unieverdedigingsmag nog in die voor-wetstadium verkeer, 'n agterstand ten opsigte van die ander dominiums gehad het, het die Suid-Afrikaanse militêre verteenwoordigers op die militêre onder-konferensie in elk geval van die reeds genoemde verwikkelinge en die inhoud van die volgende memorandums kennis geneem:

i. Aangaande bevorderingseksamens vir Staande Mag-offisiere in die dominiums.

ii. Aangaande opleidingskursusse in die Verenigde Koninkryk en Indië van offisiere uit die dominiums.

iii. Met betrekking tot die dienste wat die inspekteur-generaal van die oorsese magte kan aanbied indien dominiale regerings dit begeer.

iv. In verband met offisiersopleiding aan stafkolleges ${ }^{21}$. 
Met betrekking tot Britse offisiere wat in Januarie 1909 militêre werksaamhede in Suid-Afrika verrig het, is die volgende gegewens verstrek:

\begin{tabular}{|c|c|c|c|c|}
\hline Rang en Naam & Korps & Aanstelling & Van & Tot \\
\hline $\begin{array}{l}\text { Hon. Kapt. } \\
\text { M. C. Rowland }{ }^{22}\end{array}$ & $\begin{array}{l}\text { Royal Dublin } \\
\text { Fusiliers }\end{array}$ & $\begin{array}{c}\text { Stafoffisier } \\
\text { Transvaal } \\
\text { Volunteers }\end{array}$ & 15. 2.1903 & Op datum \\
\hline $\begin{array}{l}\text { Kapt. } \\
\text { J. C. Hanna }{ }^{23}\end{array}$ & $\begin{array}{l}\text { Royal } \\
\text { Artillery }\end{array}$ & $\begin{array}{l}\text { Adjudant } \\
\text { Cape Garrison } \\
\text { Artillery }\end{array}$ & 14. 1.1905 & Op datum \\
\hline $\begin{array}{l}\text { Kapt. } \\
\text { R. W. White }\end{array}$ & $\begin{array}{l}\text { Royal } \\
\text { Artillery }\end{array}$ & $\begin{array}{l}\text { Adjudant } \\
\text { Transvaal } \\
\text { Artillery }\end{array}$ & 6. 8.1906 & Op datum \\
\hline $\begin{array}{l}\text { Kapt. } \\
\text { J. G. Wickham, } \\
\text { D.S.O. }\end{array}$ & $\begin{array}{l}\text { Norfolk } \\
\text { Regiment }\end{array}$ & $\begin{array}{l}\text { Adjudant } \\
\text { Imperial Light } \\
\text { Horse Transvaal }\end{array}$ & 27. 7.1906 & Op datum \\
\hline $\begin{array}{l}\text { Kapt. } \\
\text { F. S. Irvine }\end{array}$ & $\begin{array}{l}\text { Royal Army } \\
\text { Medical Corps }\end{array}$ & $\begin{array}{l}\text { Adjudant } \\
\text { Medical Service } \\
\text { Corps, Transvaal } \\
\text { Volunteers }\end{array}$ & 13.10.1906 & 12.10.1909 \\
\hline $\begin{array}{l}\text { Lt.-kol. } \\
\text { L. J. Shadwell }{ }^{24}\end{array}$ & & $\begin{array}{l}\text { Stafoffisier } \\
\text { Volunteers Cape } \\
\text { Peninsula }\end{array}$ & 23. 2.1907 & Op datum \\
\hline
\end{tabular}

Van die offisiere, afkomstig van die dominiums, wat die Camberleyse Stafkollege besoek het, het sowel maj. W. E. C. Tanner as maj. G. B. Richards, albei die kursus van 1909-1910 gevolg ${ }^{25}$.

\section{4 \\ TERUGBLIK. DIE TOEKOMS}

Die Imperiale konferensie van 1911 het tot die verlede behoort en op 3 Junie 1911, terwyl die konferensie nog aan die gang was, het genl. Botha o.m. aan genl. Smuts geskrywe:

De Regeering hier het ons geheel in hun vertrouwen genomen, met betrekking tot hulle Europeesche en andere politiek en heeft ons confidentieel alles mee gedeeld... Defence en Navy het ons ook met toe deuren bespreek - en ik moet zeg jij is de man die moest mee kwam, want mijn maters is uitplaats. Wij kwam overeen dat adviserende Militaire Comite hier zal bij gestaan worden door Minister van Defence voor elk Dominion, zoodat jij zal zoo elke paar jaar moet over komen en ik dink dit is uitstekend ${ }^{26}$.

Aangaande die ontwikkelings van die Imperiale Generale Staf tot en met 1911 kan ondermeer opgemerk word dat hierdie militêre organisasie tot 'n belangrike sentrale militêre organisasie van die toenmalige Britse ryk uitgegroei het. Militêre beskerming sowel as die handhawing en verdediging van die toenmalige wêreldryk is deur die Imperiale Generale Staf beplan. 
Tussen die Verenigde Koninkryk en die dominiums het verbindingskanale tot stand gekom waardeur o.m. die eenvormigheid van militêre opleiding en bewapening gelei is, ofskoon andersyds eie stafbestuur in die dominiums gehandhaaf is. Op dié wyse het die Imperiale Generale Staf 'n militêre organisasie geword waarin bindende sowel as uiteenlopende kragte mekaar gekruis het en wat, terselfdertyd, bevorderlik vir nouer samewerking was.

Uit die geraadpleegde Suid-Afrikaanse dokumente is dit duidelik dat die Unieregering in beginsel die Imperiale Generale Staf-gedagte omstreeks 1910 gunstig gesind was, ofskoon Ondersekretaris Bourne ernstige bedenkings ten opsigte van die doeltreffendheid en die selfbeskikkingsreg van die dominiums gekoester het.

Van 1912-1914 was die Imperiale Generale Staf ten nousie by die militêre voorbereidings betrokke wat aan die uitbreek van die Eerste Wêreldoorlog voorafgegaan het.

In hierdie verband en met betrekking tot die dominiums het F. A. Johnson verklaar:

The war planning for the land forces of the Dominions was done by British experts, particularly those of the Imperial General Staff, with assistance from officers temporary attached from the Dominions. Their plans went before the C.I.D., and thence to the respective Dominion authorities and to the British Cabinet if of major importance $e^{27}$.

In die aangehaalde skrywe van genl. Botha is o.m. melding gemaak van die besluit om ministers van dominiums lede van die Committee of Imperial Defence te maak en van die feit dat die afgevaardigdes van 1911 in spesifieke Britse en ryksgeheime ingewy is.

Op dié wyse het daar 'n sterk band tussen die rykslede tot stand gekom wat deur Johnson soos volg beskrywe is:

The overseas leaders, returning home, with a glow of self-importance after having been brought into the acroma imperii . . . appreciated better than before the precept that if we do not hang together we may hang seperately.

En hieraan voeg hy toe:

Unknown to the Dominion leaders they were also laying the basis for that organ of imperial war unity, the climax prior to the combined chiefs of staff's consolidated policymaking by separate governments, the peak of the whole history of efforts to merge the disparate units of the Empire into one effort and into one body the Imperial War Cabinet ${ }^{29}$.

Terwyl die Imperiale Oorlogskabinet sy verskyning in 1917 gemaak het, is in die loop van dieselfde jaar - die Imperiale oorlogskonferensie in Londen gehou $^{30}$.

Die Imperiale oorlogskabinet was 'n vergroting van die Britse kabinet, waarop verteenwoordigers van die dominiums sitting gehad het. Genl. J. C. Smuts het die Unie van Suid-Afrika verteenwoordig en op dié wyse is die voorspelling van genl. Louis Botha in sy skrywe van 3 Junie 1911 bewaarheid.
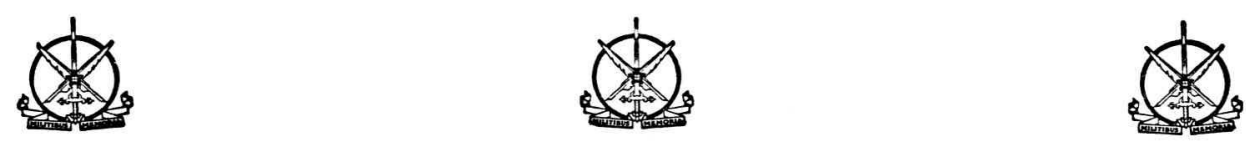


\section{SUMMARY}

During the Anglo-Boer War (1899-1902) the absence of a comprehensive Imperial military planning organisation proved to be costly to the British Empire.

In 1903 the War Office (Reconstruction) Committee under the chairmanship of Lord Esher submitted reform plans and proposed to fill the serious gap in the military organisation of the British Empire by the establishment of an Imperial General Staff.

The Imperial Conference (1907) supported this proposal and in 1908 was followed by the well-known memorandum The Imperial General Staff by General Sir William G. Nicholson, in which a military organisation was visualised for the British Empire, providing at the same time, sufficient latitude for local conditions and general staff organisations.

In 1907 Colonel P. S. Beves, on instructions from the Transvaal Prime Minister, General L. Botha, drew up a memorandum in which he welcomed the proposals, particularly in view of the fact that the Transvaal Volunteers already followed the British organisational pattern.

Whereas in terms of the Nicholson Memorandum, Canada laid particular emphasis on local General Staffs in the dominions being fully controlled by their governments and, together with Australia, agitated against unlimited military control by the Imperial General Staff, the Prime Ministers of the four British colonies in South Africa, did not express any decided views in this regard after study of the same Memorandum.

The latter felt that pending political changes prior to formation of the future Union Government, they should not be bound to any particular policy. On the other hand, General Botha and his South African colleagues welcomed the idea that South African delegates were invited to attend the Imperial Conference of 1909 at which they would be able to discuss the future South African defence organisation and system, which would, in all probability, resemble the pattern already set within the British Empire. The said conference was, subsequently attended by Prime Minister J. X. Merriman (Cape Colony), Minister (Colonel) E. M. Greene, K.C., (Natal), Colonial Secretary General J. C. Smuts (Transvaal), Prime Minister A. Fischer and Attorney-General General J. B. M. Hertzog (Orange River Colony).

Brigadier-General C. G. Ashton, C.B., and Colonel P. S. Beves were present at certain military meetings. The South African colonial governments incurred no commitments at these meetings.

Undersecretary Bourne (Transvaal) drew an interesting parallel between the British and German concepts of General Staff organisation. Whilst the latter envisaged centralisation, the former concept contained decentralised aspects.

During the later Imperial Conference of 1911, attended by the Prime Minister, General L. Botha, South African delegates noted further developments in reference to the existing political situation in Europe. Subsequently British experts, temporarily assisted by officers of the different dominions, engaged in war planning in regard to the land forces of the dominions and in this way strengthened the existing military bonds between the various components of the British Empire.

In 1917 General J. C. Smuts represented the Union of South Africa in the Imperial War Cabinet.
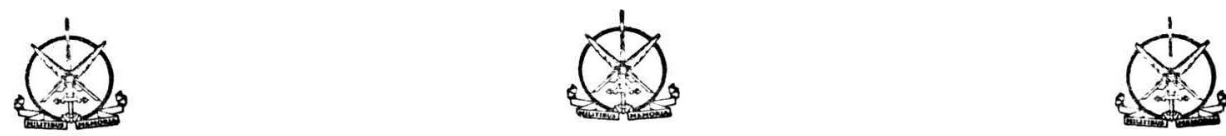


\section{AANTEKENINGE}

1. F. A. Johnson, Defence by Committee, (London, 1960), p. 63. Hoofsaaklik hoofstukke 2 en 3.

2. Ibid., pp. 68-69.

3. Ibid., p. 68 .

4. Ibid., p. 88 .

The Army Quarterly, deel 1, nr. 1, Okt. 1920, waarin „The Staff,” pp. 19-35.

5. Met betrekking tot die begrip nasionale verdediging merk genl. N. op dat dit, wat die Britse ryk betref, plaaslike- en Imperiale verdediging beteken.

6. Cd. 4948 , nr. 11 , pp. 5-7.

7. Ibid., p. 6, o.m. gevolg deur nr. 12, p. 7.

8. Ibid., nr. 18, p. 17.

9. Ibid., nr. 21 (12.5.1909), nr. 23 (13.5.1909), nr. 26 (15.5.1909). In aansluiting hierop: Nrs. 32 (5.6.1909), 33 (5.6.1909); met byvoegsels.

10. Ibid., p. 17. Vergaderings gehou op 28 en 29 Julie, 3, 5, 6 en 19 Augustus 1909.

11. Ibid., p. 18 en p. 29.

12. Ibid., pp. 39-41. In opgesomde vorm is die Kanadese en Australiëse voorstelle en kommentare op pp. 42-43 gepubliseer. Sien ook organigramme op pp. 48-52.

13. Uit ander amptelike Suid-Afrikaanse bronne blyk dit dat daar ook geheime besprekings oor die Imperiale Generale Stafvraagstuk tydens dié konferensie gehou is.

14. In 'n ongedateerde aantekening het B. onder meer verklaar dat, ten spyte van eenvormigheid, die vraagstuk ten opsigie van die oorlogsterrein vir buitelandse troepe in 'n bepaalde land sou bly bestaan. Hy teken verder aan: Thus supposing the Germans were invading South Africa from the East and that 20000 Canadians came from the West to our assistance, the real difficulties of the Canadian contingent could be the want of familiarity with the actual South African conditions and tactics required to cope with those conditions, and the great physical differences of climate.

15. Cd. 5741, pp. 2-3. Voorafgaande briefwisseling ondermeer in Cd. 5513, pp. 10, 15.

16. Ibid., p. 6.

17. Ibid., p. 5.

18. Cd. $5746-2$. Na dié Blouboek is in Cd. 5745 , p. 432 (verrigtings van 20 Junie 1911) verwys.

19. Cd. $5746-2$, p. 4 e.v.

20. Die Kanadese tak was soos volg saamgestel: Hoof van die Generale Staf en eerste militêre lid van die Milisieraad; die Direkteur van Operasies en Stafpligte, die Kommandant van die Koninklike Militêre Kollege, Kingston; professors van genoemde kollege. Daar was nog ses Generale Staf-offisiere benodig. Australië: Die Hoof van die Generale Staf, die Direkteur van Verdedigingsorganisasie, die Direkteur van Militêre Opleiding, die Direkteur van Inligting.

21. Cd. $5746-2$, pp. $7-14$.

22. Die latere kol. M. C. Rowland het op 24.6 .1882 sy militêre loopbaan by die Royal Munster Fusiliers begin. Op 2.3.1898 het sy oorplasing, in die rang van luitenant, na die Royal Dublin Fusiliers gevolg. Kaptein: 29.11.1900, Majoor: 28.6.1907. Diens in Suid-Afrika: 1901-1903, betaalmeester S. A. Constabulary; 1903-1907, betaalmeester en kontroleur Transvaal Volunteers; 1908-1912, stafoffisier Administrasie Transvaal Volunteers. In die rang van luitenant-kolonel: 1.7.1912-31.8.1914, stafoffisier, Unieverdedigingsmag (U.V.M.) Staande Mag, in bevel van administrasie 1.9.1914-23.6.1917. Kolonel, kwartiermeester-generaal U.V.M. - 2.6.1919.

23. Van 1878-1879 lid van die Beaufort West Rifles, van 1893-1895 Natal Carbineers; van 1899-1902 kaptein, Nesbit's Horse; 1905-1906 kaptein, Natal Mounted Rifles. Reserwe van Offisiere: 5.8.1909, luitenant in Suidwes-Afrika (1918); kaptein, 1918-1919. 
24. Die latere luitenant-kolonel L. J. Shadwell was, voordat hy diens by die Transvaal Volunteers aanvaar het, op Middelburg (K.K.) gestasioneer. Op 12.2.1909 is sy diens met twee jaar verleng. Uit ander bronne is bekend dat hy sy militêre loopbaan omstreeks 1880 as lid van die Cambridge Militaria begin het, van 1885-1890 adjudant van die Ist Suffolk Regiment was, 'n stafkollege besoek het, in Indië met militêre opleiding belas was en vervolgens tweede in bevel van die 3rd Lancashire Fusiliers (Middelburg, K.K.) en daarna stafoffisier Cape Peninsula Volunteers was. Na sy dienstydperk in Transvaal benoem as stafoffisier Militêre Distrik No. 1 (Kaapse Skiereiland), seksiekommandant verdedigingswerke Tafelbaai 1914-1915. Op 1.8.1915 vrygestel om militêre diens in Engeland te verrig.

25. Cd. $5746-2$, p. 18.

26. W. K. Hancock en J. van der Poel, Selections from Smuts Papers, Cambridge, 1966) deel 3, p. 498. Sien ook: W. K. Hancock, Smuts, the Sanguine Years 1870-1919. (Cambridge, 1962), p. 353.

27. Defence by Committee, pp. 125-126.

28. Ibid., p. 114 .

29. Ibid., p. 114. Sien ook Cd. 9005. The War Cabinet. Report for the year 1917, p. 5.

30. Cd. 8566 . 